\title{
Domino reaction sequences leading to the formation of 2:2 adducts between acenaphthenequinone and acetophenone
}

\author{
Jomon P. Jacob, ${ }^{a}$ Christy Kunjachan, ${ }^{a}$ L. U. Sajitha, ${ }^{a}$ Roshini K. Thumpakara, ${ }^{a}$ \\ K. Rakesh,${ }^{b}$ V. Nidhisha, ${ }^{b}$ Perupparampil A. Unnikrishnan, ${ }^{a}$ and Sreedharan Prathapan ${ }^{* a}$ \\ ${ }^{a}$ Department of Applied Chemistry, Cochin University of Science and Technology, \\ Cochin 682 022, Kerala, India \\ ${ }^{b}$ Postgraduate Department of Chemistry, St. Mary's College, Sulthan Bathery 673 592, \\ Wayanad District, Kerala, India \\ E-mail:prathapans@gmail.com
}

DOI: http://dx.doi.org/10.3998/ark.5550190.p008.834

\begin{abstract}
A Michael-aldol domino reaction sequence of acenaphthenequinone with acetophenone in the presence of $\mathrm{KOH}$ in methanol solvent leading to the formation of three different 2:2 adducts arising through three distinct reaction sequences is described. Similar sequences leading to a highly substituted furan derivative were observed in the reaction between phenanthrenequinone and acetophenone.
\end{abstract}

Keywords: Domino reaction, acenaphthenequinone, dispiro compounds, Claisen-Schmidt condensation, phenanthrenequinone

\section{Introduction}

Current research in organic synthesis focuses on atom economy. The efficiency of a synthetic sequence is fortified by multiple bond-forming and catalytic chemical processes. The efficiency can be measured by parameters such as selectivity, overall yield, raw material, time, human resources, energy requirements, toxicity and hazard of the chemicals. Therefore step count and product yield in individual steps are important criteria when evaluating the efficiency of a synthesis. More specifically, domino and multicomponent reactions are now the cornerstone to atom economy in synthesis. Domino and/or multicomponent reactions have been used largely for the synthesis of large libraries of heterocyclic, potentially bioactive molecules and, to a lesser extent, the total synthesis of complex molecules. ${ }^{1-13}$

A domino sequence of Michael addition and aldol condensation is an attractive strategy for constructing complex molecular architectures. ${ }^{14-16}$ The success of this strategy is revealed in the total synthesis of naturally occurring anti-Alzheimer product huperzine A. ${ }^{17}$ In this article, we 
report domino reaction sequences leading to unusual product formation in the reaction between reactive 1,2-diketones and acetophenone.

\section{Results and Discussion}

Acenaphthenequinone, like benzil, is expected to undergo Claisen-Schmidt condensation with acetophenone to give 2-(2-oxo-2-phenylethylidene)acenaphthylen-1(2H)-one (3a). The structural features of $\mathbf{3 a}$ indicate that it can be considered as a highly reactive quinonemethide that can undergo further transformations. In an earlier report, ${ }^{18}$ we described the formation in low yield of a new product tentatively identified as a highly substituted dispiro compound 2'-benzoyl-4'hydroxy-5'-methoxy-4'-phenyl-2H,2" $H$-dispiro[acenaphthylene-1,1'-cyclopentane-3',1"-acenaphthylene]-2,2"-dione (4a) by a novel solvent-assisted Michael-aldol reaction of 3a (Scheme 1).
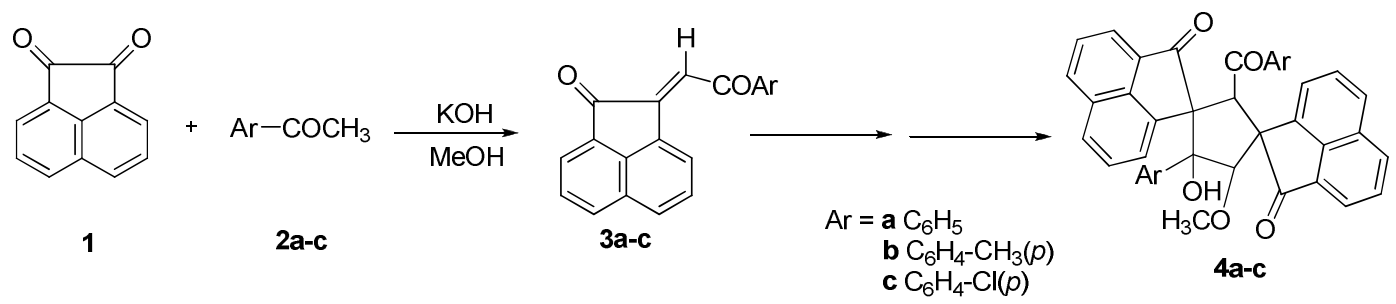

Scheme 1. Solvent-assisted Michael-aldol reaction between acenaphthenequinone and acetophenones.

The generality of this domino reaction sequence was established using substituted acetophenones such as 4-chloroacetophenone (having an electron-withdrawing group) and 4-methylacetophenone (with an electron-releasing group). ${ }^{18}$ We re-examined the base-catalysed reaction of $\mathbf{1}$ and 2a-c to optimize yields, isolate other products, if any, and to understand the mechanism involved. We have now isolated and identified two novel 2:2 adducts formed along with the reported substituted dispiro compound that is also a 2:2 adduct.

The reaction of acenaphthenequinone (1) with acetophenone (2a) in the presence of $\mathrm{KOH}$ in methanol was completed in 4 hours. TLC analysis of the dark brown reaction mixture indicated the presence of three products. The products were separated by column chromatography over silica gel. Two of the products (4a and 2'-benzoyl-4'-hydroxy-4'-phenyl-2H,2" $H$ dispiro[acenaphthylene-1,1'-cyclopentane-3',1"-acenaphthylene]-2,2"-dione (5a)) were relatively nonpolar and were colourless solids, while the third highly polar compound 8-(7,8-dibenzoyl$7 H$-cyclopenta[ $a$ ]acenaphthylen-9-yl)-1-naphthoic acid (6a) was obtained as a red solid. Compound 4a was identified as the dispiro compound reported earlier. ${ }^{18}$ Mass spectroscopic analysis of 5a indicated that it is a 2:2 adduct between acenaphthenequinone and acetophenone. In the ${ }^{1} \mathrm{H}$ NMR spectrum of 5a, a one-proton singlet was observed at $\delta 5.60$ and two one proton doublets were seen at $\delta 4.55(J=14 \mathrm{~Hz})$ and $2.67(J=14 \mathrm{~Hz})$, along with signals for 22 aromatic protons. The structure of $\mathbf{5 a}$ was unequivocally established on the basis of single crystal X-ray analysis (Figure 1). 


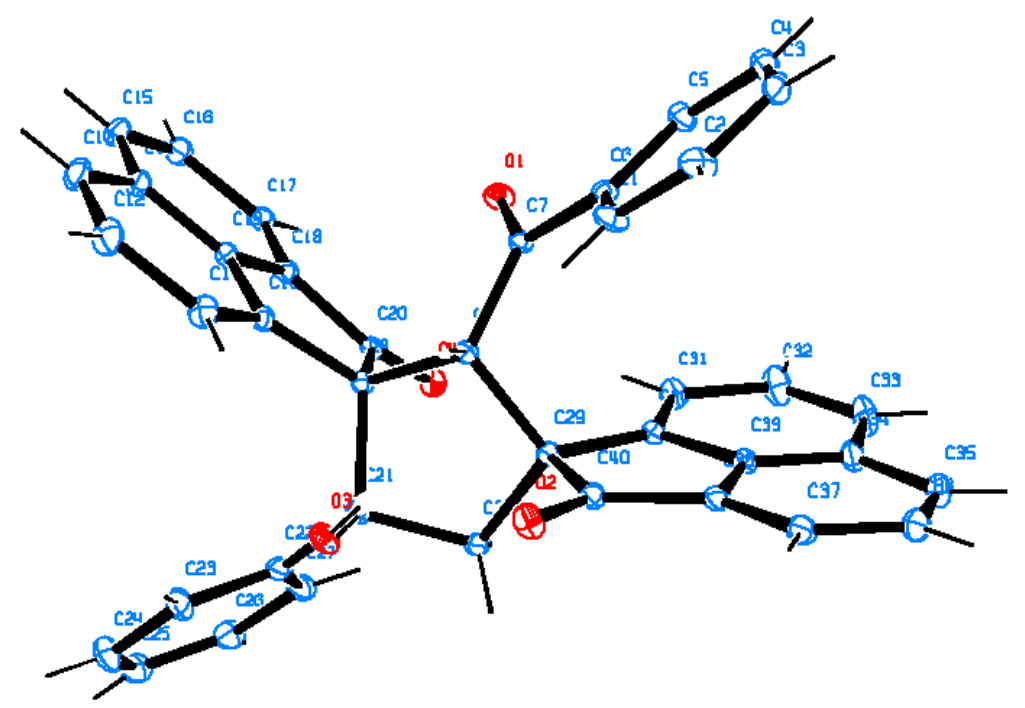

Figure 1. ORTEP diagram of molecular structure of 5a.

Compound 6a was highly polar in nature and hence separation and purification of this material was challenging. It was separated by elution with a 1:1 mixture of methanol and ethyl acetate. Tarry material that co-eluted with 6a was separated by repeated washing with cold methanol. An analytically pure sample of $6 \mathbf{a}$ was generated by repeated recrystallization from a mixture of ethyl acetate and dichloromethane. Mass spectroscopic analysis of $6 \mathbf{a}$ indicated that it was also a 2:2 adduct. Poor solubility of this compound in almost all solvents foiled our attempts to record its ${ }^{13} \mathrm{C}$ NMR spectrum. However, a ${ }^{1} \mathrm{H}$ NMR spectrum of acceptable quality could be recorded and it showed signals for aromatic protons only. The IR spectrum of the compound indicated the presence of both a carboxylic acid and another carbonyl group. Based on the available data, we assigned the structure of the new product as the naphthoic acid derivative $6 \mathbf{a}$ (Chart 1).

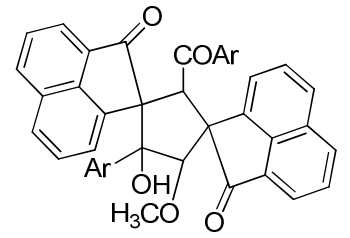

$4 a$

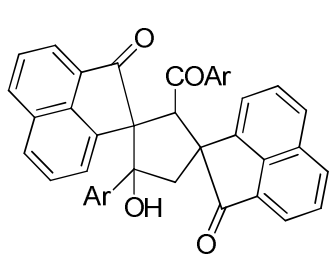

$5 \mathbf{a}$



$\mathrm{Ar}=\mathrm{C}_{6} \mathrm{H}_{5}$

$6 \mathbf{a}$

Chart 1. 2:2 Adducts formed between acenaphthenequinone and acetophenone.

We repeated the base catalyzed reaction of acenaphthenequinone with 4-methylacetophenone $(\mathbf{2 b})$ and 4-chloroacetophenone (2c) to examine the generality of the reaction. Three products, each analogues to $\mathbf{4 a}, \mathbf{5 a}$ and $\mathbf{6 a}$, were formed in these reactions indicating 
similarity in the reaction between acenaphthenequinone and acetophenone derivatives. Fortunately, diffraction quality crystals of 8-[7,8-bis(4-chlorobenzoyl)-7H-cyclopenta[a]acenaphthylen-9-yl]-1-naphthoic acid (6c) formed in the reaction between acenaphthenequinone and 4-chloroacetophenone could be isolated. Single crystal X-ray diffraction analysis of 6c confirmed its identity as a 2:2 adduct (Figure 2).

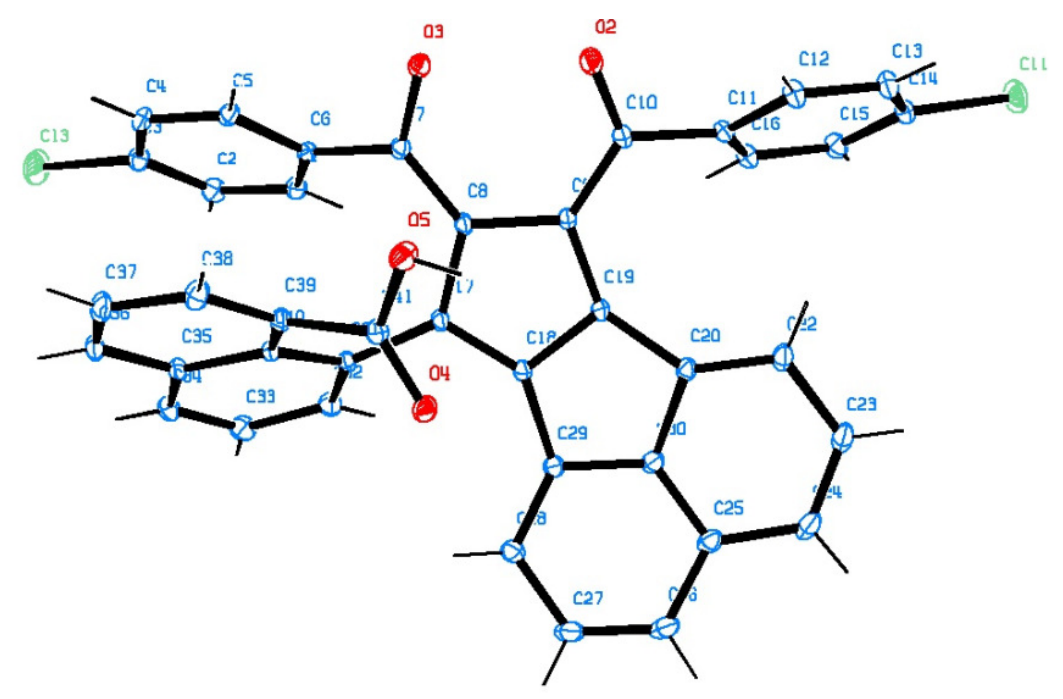

Figure 2. ORTEP diagram of molecular structure of $\mathbf{6 c}$.

A possible mechanism for the formation of 2:2 adducts 4-6 through a common intermediate $\mathbf{3}$ formed by the Claisen-Schmidt reaction between acenaphthenequinone (1) and acetophenone (2) is provided in Scheme 2. A solvent-assisted domino reaction sequence leading to 4a-c was reported earlier. ${ }^{18}$ We invoke $\mathbf{3}$ as an intermediate for the generation of 5a-c and $\mathbf{6 a - c}$ as well. It may be noted that nucleophilic addition to enediones such as $\mathbf{3}$ can take place at two different centers (marked by solid arrows in Scheme 2). Attack of methanol (path a) leads to the formation of intermediate 9 that adds to another molecule of $\mathbf{3}$ to give the 2:2 adduct $\mathbf{1 0}$ that then undergoes intramolecular Claisen-Schmidt condensation to give dispiro-compounds 4a-c. Addition of a second molecule of acetophenone to $\mathbf{3}$ (paths a $\&$ b) would give rise to Michael adducts $\mathbf{7}$ and $\mathbf{8}$ respectively. Condensation of $\mathbf{8}$ with a second molecule of acenaphthenequinone yields the second 2:2 adduct 14. Intramolecular carbonyl-olefin coupling followed by H-abstraction leads to the formation of 5a-c. The mechanism of carbonyl-olefin cyclization is understood in terms of ketyl intermediates generated by single electron transfer to the carbonyl group. Single electron transfer mediated carbonyl-olefin cyclizations ${ }^{19,20}$ and single electron transfer from nucleophiles $^{21}$ are well documented in the literature. We assume that the presence of a highly electron deficient molecule such as acenaphthenequinone under strongly basic conditions enables electron transfer reactions leading to eventual carbonyl-olefin cyclization indicated in Scheme $2 .^{22,23}$ 
Formation of 6a-c was even more puzzling. Base-catalyzed ring opening of acenaphthenequinone to give the corresponding naphthoic acid derivative in a benzil-benzilic acid type reaction sequence is reported in the literature. ${ }^{24}$ In a similar way, crossed benzilbenzilic acid type reaction between $\mathbf{7}$ and $\mathbf{1 1}$ would enable a unique carbon-carbon bond forming reaction to give yet another 2:2 adduct 12 that undergoes intramolecular Claisen-Schmidt condensation and loss of water to give $\mathbf{6 a - c}$.

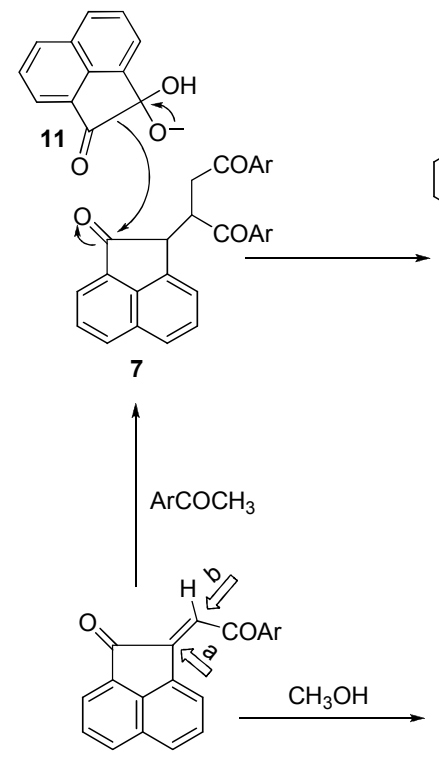

3

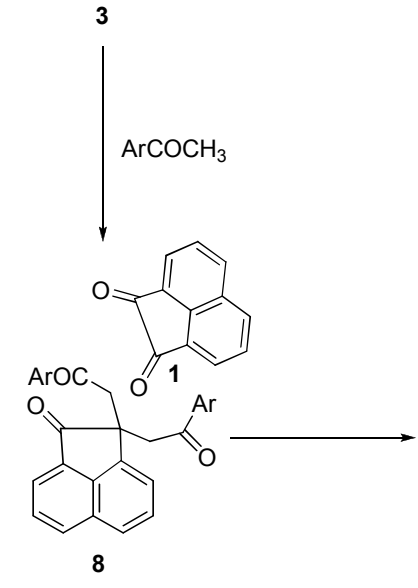

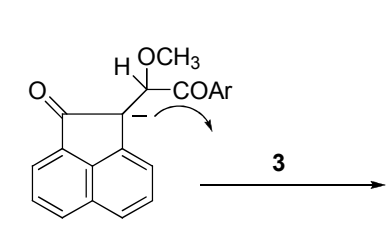

9

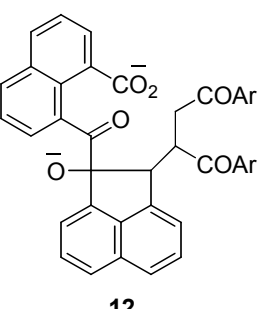

12
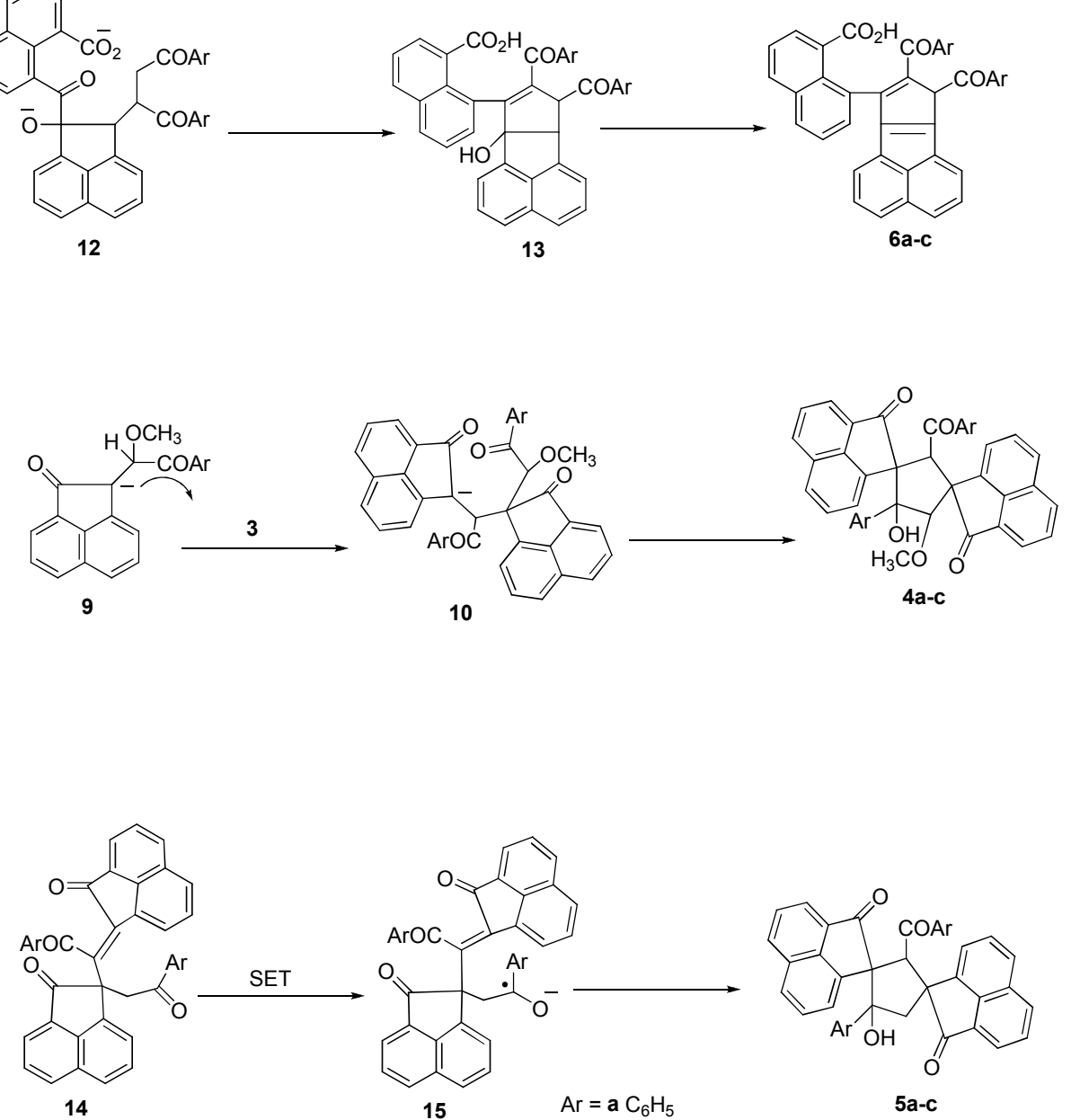

10

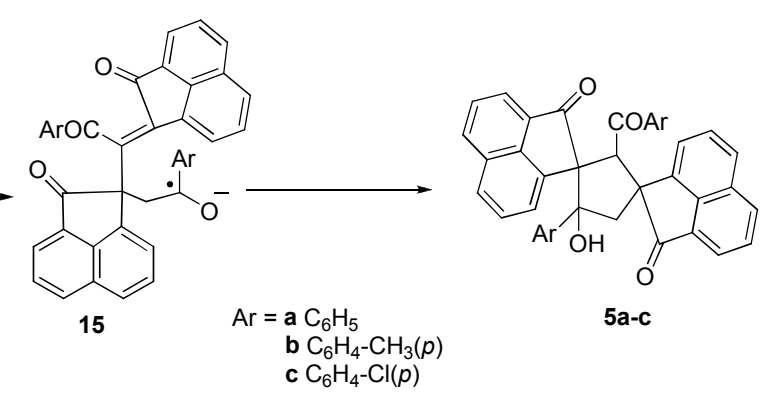

Scheme 2. Proposed mechanism for the formation of 2:2 adducts between acenaphthenequinone and acetophenone.

In order to establish the intermediacy of $\mathbf{3}$ in the generation of 2:2 adducts 4-6, we independently synthesised 3a by adopting the Wittig route. Independently synthesized 3a was totally consumed on further reaction with acenaphthenequinone and acetophenone in the presence of potassium hydroxide in methanol. Work up of the reaction mixture yielded dispirocompounds 4a, 5a and 6a (Scheme 3) in a 9:3:1 ratio that is close to the ratio at which these 
products are formed in the reaction between $\mathbf{1}$ and 2a. Furthermore, in two different control experiments, we established that $\mathbf{4 a}$ and $\mathbf{5 a}$ do not interconvert under the conditions employed by us. Prolonged treatment of $\mathbf{4 a}$ with acenphthenequinone in methanol in the presence of base did not result in any noticeable change. Similarly, 5a was also recovered unchanged after attempted reaction with acenaphthenequinone in methanol in the presence of base. These experiments support the mechanistic pathways depicted in Scheme 2 for independent generation of the three 2:2 adducts.

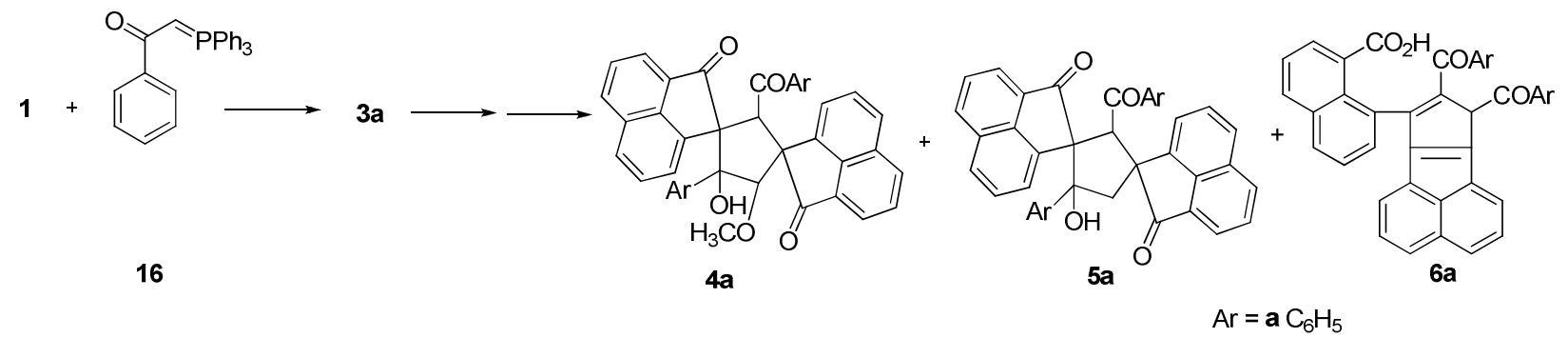

Scheme 3. Control experiment employing independently synthesized 3a.

In a related experiment, we repeated the reaction of phenanthrenequinone (17) with 4chloroacetophenone (2c) ${ }^{25}$ We could separate dihydrofuranol 18 as the major product along with a novel furan derivative (4-chlorophenyl)[2-(10-hydroxyphenanthren-9-yl)phenanthro[9,10b]furan-3-yl]methanone (21) in minor amounts. Generation of 21 can be understood in terms of a domino sequence involving multiple Claisen-Schmidt condensations and nucleophilic additions as described in Scheme 4.
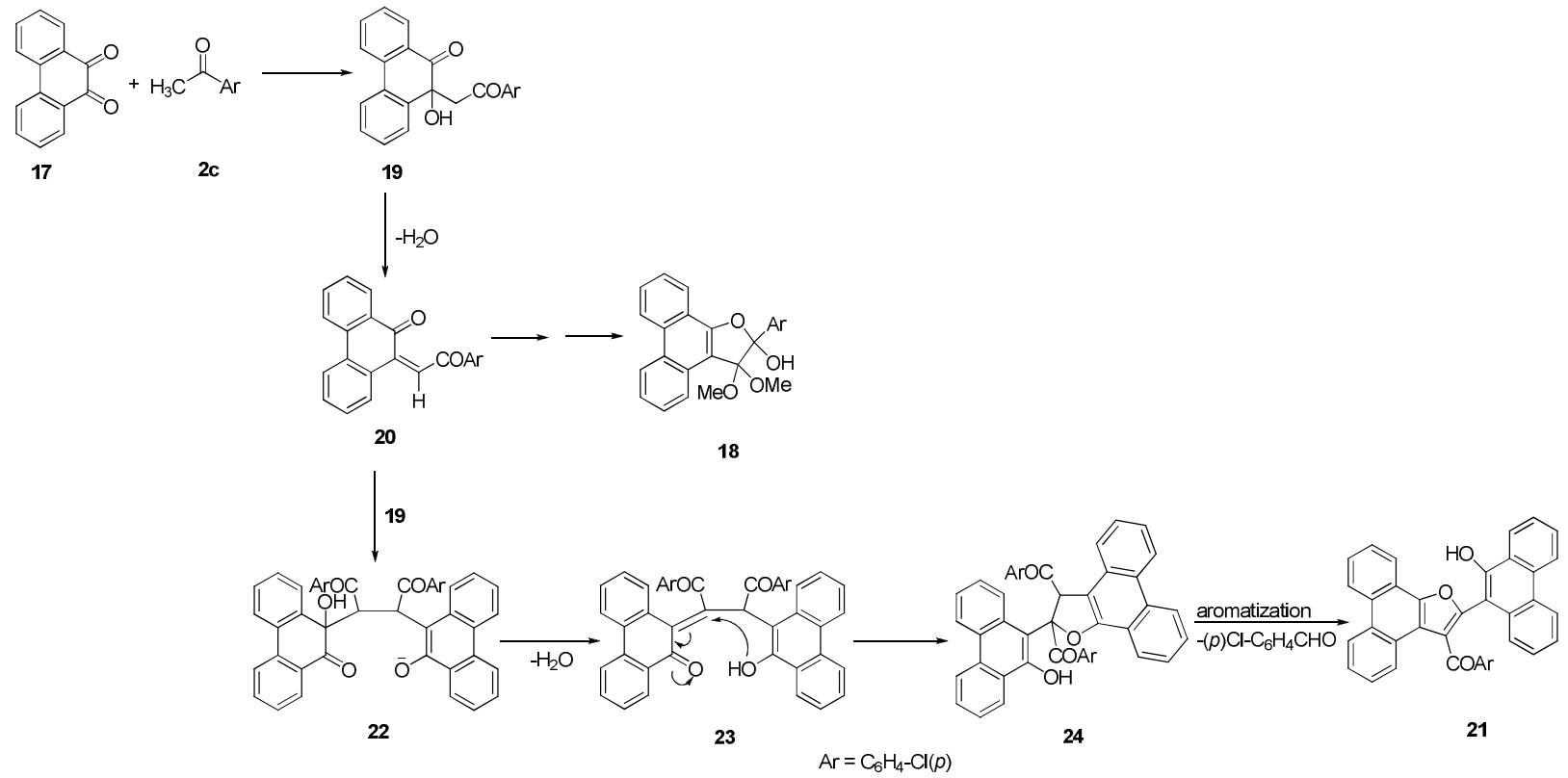

Scheme 4. Mechanism for the domino reaction between 17 and 2c. 
Michael addition of aldol $\mathbf{1 9}$ to enedione $\mathbf{2 0}$ is the key step in the generation of furan $\mathbf{2 1}$. Subsequent dehydration, intramolecular Michael type addition and aromatization with the elimination of elements of 4-chlorobenzaldehyde completes the unusual reaction sequence for the formation of $\mathbf{2 1}$. We could not record the ${ }^{13} \mathrm{C}$ NMR spectrum of $\mathbf{2 1}$ due to the poor solubility of this compound in common solvents. The structure of $\mathbf{2 1}$, however, could be established on the basis of single crystal X-ray diffraction analysis (Figure 3).

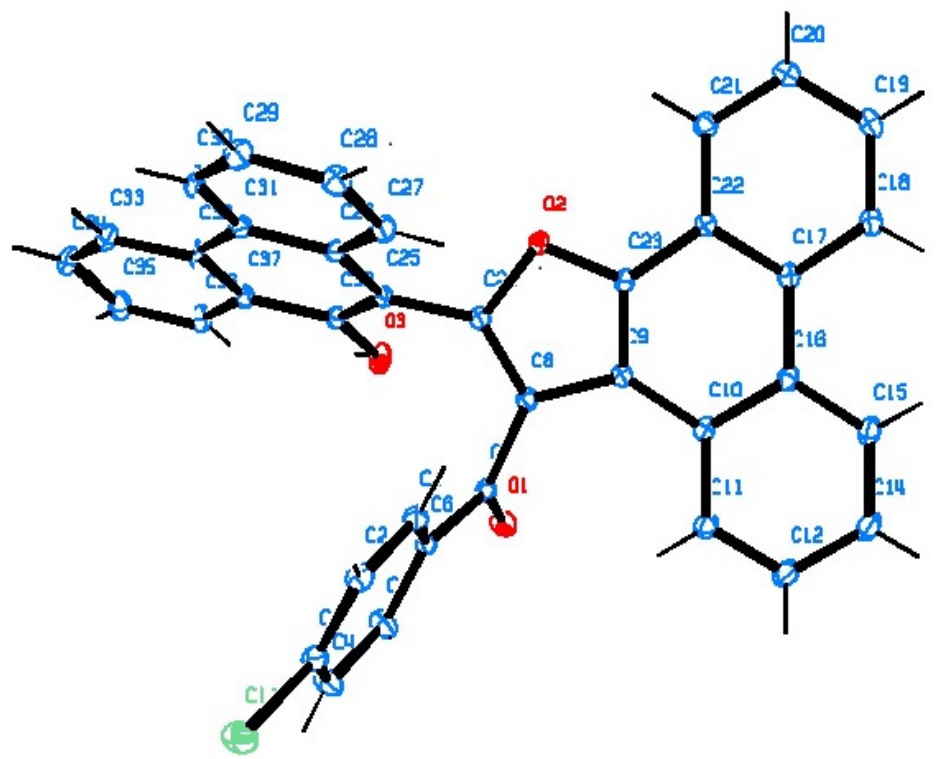

Figure 3. ORTEP diagram of molecular structure of 21.

\section{Conclusions}

We have demonstrated the independent generation of three 2:2 adducts in the base catalysed reaction between acenaphthenequinone and acetophenone in methanol. Domino reaction sequences for the formation of various products are proposed. The structures of the adducts were established on the basis of ${ }^{1} \mathrm{H}$ NMR, ${ }^{13} \mathrm{C}$ NMR and SCXRD analyses. A domino reaction sequence is possible with other cyclic 1,2-diones such as phenanthrenequinone as well.

\section{Experimental Section}

General. All reactions were conducted in oven-dried glassware. Reagents used were purchased from Aldrich Chemical Co. or Spectrochem and were used without further purification. Solvents used for experiments were distilled and dried according to procedures given in standard manuals. All reactions were monitored by thin layer chromatography (TLC). Analytical thin layer chromatography was performed on aluminium sheets coated with silica gel (Spectrochem); visualization was achieved by exposure to iodine vapours or UV radiation. Solvent removal was 
done on a Heidolph rotary evaporator. Gravity column chromatography was performed using 60120 mesh silica gel (Spectrochem) and mixtures of hexane-ethyl acetate were used for elution. Melting points were recorded on a Neolab melting point apparatus. Infrared spectra were recorded using JASCO FTIR 4100 spectrometer. NMR spectra were recorded on $400 \mathrm{MHz}$ Bruker FT-NMR spectrometer. Chemical shifts are reported in $\delta(\mathrm{ppm})$ relative to TMS as the internal standard. Single Crystal XRD was done by Bruker XRD Instrument. Elemental analysis was performed using Elementar Systeme (Vario EL III). Molecular mass was determined by fast atom bombardment (FAB) using JMS 600 JEOL mass spectrometer. Unless otherwise mentioned, all commercially available solvents and reagents were used as received and reactions were performed under normal conditions.

\section{Reaction between acenaphthenequinone (1) and acetophenones (2a-c): typical procedure} A mixture of acenaphthenequinone (1, $4.6 \mathrm{~g}, 25 \mathrm{mmol})$, acetophenones (2a-c, $27 \mathrm{mmol})$ and powdered $\mathrm{KOH}(1.0 \mathrm{~g})$ in $\mathrm{MeOH}(30 \mathrm{~mL})$ was stirred around $60{ }^{\circ} \mathrm{C}$ for $4 \mathrm{~h}$ and later kept in refrigerator for $48 \mathrm{~h}$. The reaction mixture was concentrated and the residue was purified by chromatography over silica gel. Products 4a-c (45-48\%)and 5a-c (5-12\%) were obtained by elution with a mixture of hexane and EtOAc (9:1). Elution with a mixture of MeOH-EtOAc (1:1) yielded the product 6a-c (2-5\%). Diffraction quality crystals of products $4 \mathbf{a}$ and 5a were generated by crystallization from xylene $(0.15 \mathrm{~g}$ in $5 \mathrm{~mL})$ while those of $\mathbf{6 c}$ were obtained by slow evaporation of solvent from a solution of $\mathbf{6 c}$ in a mixture (1:1) of EtOAc and $\mathrm{CH}_{2} \mathrm{Cl}_{2}(0.20$ $\mathrm{g}$ in $5 \mathrm{~mL}$ ).

Reaction of phenanthrenequinone (17) with 4-chloroacetophenone (2c). A mixture of phenanthrenequinone (17, $5.2 \mathrm{~g}, 25 \mathrm{mmol})$, 4-chloroacetophenone (2c, $4.2 \mathrm{~g}, 27 \mathrm{mmol})$ and powdered $\mathrm{KOH}(1.0 \mathrm{~g})$ in $\mathrm{MeOH}(30 \mathrm{~mL})$ was stirred around $60{ }^{\circ} \mathrm{C}$ for $48 \mathrm{~h}$ and later kept in refrigerator for $48 \mathrm{~h}$. The solid product obtained was separated by filtration and identified as dihydrofuranol 18 (65\%). After filtration, the reaction mixture was concentrated and chromatographed over silica gel. Elution with a mixture (2:3) of hexane and EtOAc gave highly substituted furan $\mathbf{2 1}$ (12\%). Diffraction quality crystals of $\mathbf{2 1}$ were generated by slow evaporation of its solution in $\mathrm{MeOH}(0.15 \mathrm{~g}$ in $5 \mathrm{~mL})$.

\section{Independent synthesis of acenaphthenone -2-ylidene ketone 3a}

a) Synthesis of 2-bromo-1-phenylethanoyltriphenylphosphonium bromide. A solution of phenacyl bromide $(5.0 \mathrm{~g}, 25 \mathrm{mmol})$ in $\mathrm{CHCl}_{3}(5 \mathrm{~mL})$ was added in portions over a period of 15 min to a $\mathrm{CHCl}_{3}$ solution $(6 \mathrm{~mL})$ of triphenylphosphine $(6.5 \mathrm{~g}, 25 \mathrm{mmol})$. The solution was filtered into one litre of anhydrous $\mathrm{Et}_{2} \mathrm{O}$. The precipitate, 2-bromo-1phenylethanoyltriphenylphosphonium bromide was collected, dried and recrystallized from water to give the title compound in the form of white powder $\left(68 \%\right.$, mp $\left.267^{\circ} \mathrm{C}\right) .{ }^{26}$

b) Synthesis of triphenylphosphinebenzoylmethylene (16). A mixture of 2-bromo-1phenylethanoyltriphenylphosphonium bromide $(7.0 \mathrm{~g})$ and $10 \%$ of aq $\mathrm{Na}_{2} \mathrm{CO}_{3}(250 \mathrm{~mL})$ was shaken for $15 \mathrm{~h}$. The mixture was filtered and the insoluble portion was taken up in hot benzene 
$(200 \mathrm{~mL})$. Some unreacted bromide was removed by filtration, addition of $\mathrm{Et}_{2} \mathrm{O}$ to the benzene filtrate afforded the compound (benzoylmethylene)triphenylphosphine-P(V) (16) as a white powder $\left(65 \%, \mathrm{mp} .178-180^{\circ} \mathrm{C}\right) .^{27}$

c) Synthesis of 2-(2-oxo-2-phenylethylidene)acenaphthylen-1(2H)-one (3a). A solution of 1 $(5.3 \mathrm{~g}, 27 \mathrm{mmol})$ and benzoylmethylenetriphenylphosphine-P(V) (16, $10.3 \mathrm{~g}, 27 \mathrm{mmol})$ in EtOH $(30 \mathrm{~mL})$ was stirred at $\mathrm{rt}$ for $2 \mathrm{~h}$. The solid product $(4.3 \mathrm{~g})$ that separated out was purified by recrystallization from a $1: 1 \mathrm{EtOH}-\mathrm{CHCl}_{3}$ mixture $(25 \mathrm{~mL})$ to give $4.1 \mathrm{~g}$ of compound $\mathbf{3 a}$ as yellow needles.

\section{Conversion of 3 into 4, 5 and 6}

An equimolar mixture of acenaphthenequinone (1), acetophenone (2a) and independently synthesized 3a in $\mathrm{MeOH}$ in the presence of $\mathrm{KOH}$ was stirred at $60{ }^{\circ} \mathrm{C}$ for $4 \mathrm{~h}$ and later kept in a refrigerator for $48 \mathrm{~h}$. The reaction mixture was concentrated and the residue was chromatographed over silica gel. Products 4a (45\%) and 5a (14\%) were obtained on elution with a mixture (9:1) of hexane and EtOAc. Elution with a mixture (1:1) of $\mathrm{MeOH}$ and EtOAc yielded 6a $(5 \%)$.

\section{Attempted conversion of $4 a$ into 5 a}

In a control experiment, an equimolar mixture of $\mathbf{1}$ and $\mathbf{4 a}$ in the presence of $\mathrm{KOH}$ in $\mathrm{MeOH}$ was stirred at $60{ }^{\circ} \mathrm{C}$ for $4 \mathrm{~h}$ and later kept in refrigerator for $48 \mathrm{~h}$. The reaction mixture was concentrated and the residue was chromatographed over silica gel. Unreacted $\mathbf{1}$ and $\mathbf{4 a}$ were recovered in quantitative yield.

\section{Attempted conversion of 5 a to 4 a}

In another control experiment, an equimolar mixture of $\mathbf{1}$ and $\mathbf{5 a}$ in the presence of $\mathrm{KOH}$ in $\mathrm{MeOH}$ was stirred at $60{ }^{\circ} \mathrm{C}$ for $4 \mathrm{~h}$ and later kept in a refrigerator for $48 \mathrm{~h}$. The reaction mixture was concentrated and the residue was chromatographed over silica gel. Unreacted $\mathbf{1}$ and $\mathbf{5 a}$ were recovered in quantitative yield.

\section{Characterization Data}

2-(2-Oxo-2-phenylethylidene)acenaphthylen-1(2H)-one (3a). Yield $5.0 \mathrm{~g} \mathrm{(60 \% );} \mathrm{mp} 108{ }^{\circ} \mathrm{C}$, IR (KBr): 1722, $1671(\mathrm{C}=\mathrm{O}) \mathrm{cm}^{-1} ;{ }^{1} \mathrm{H} \mathrm{NMR}\left(\mathrm{CDCl}_{3}\right): \delta 8.97-7.26(\mathrm{~m}, 12 \mathrm{H}$, aromatic and vinylic), ${ }^{13} \mathrm{C} \mathrm{NMR}\left(\mathrm{CDCl}_{3}\right): \delta 200.3,199.2,141.1,140.8,138.1,134.9,133.3,131.0,130.9$, 130.4, 129.2, 128.4, 128.3, 127.6, 126.1, 123.2, 118.3, 96.4; MS: $m / z 284\left(\mathrm{M}^{+}\right)$; Anal. Calcd for $\mathrm{C}_{20} \mathrm{H}_{12} \mathrm{O}_{2}$ : C: 84.49, H: 4.25; Found: C: 84.23, H: $4.10 \%$.

2'-Benzoyl-4'-hydroxy-4' -phenyl-2H,2" $H$-dispiro[acenaphthylene-1,1'-cyclopentane-3',1"acenaphthylene]-2,2" -dione (5a): Yield $1.7 \mathrm{~g}(12 \%)$; mp >250 ${ }^{\circ} \mathrm{C}$; IR (KBr): $3336(\mathrm{OH}), 1707$ $(\mathrm{C}=\mathrm{O}) \mathrm{cm}^{-1} ;{ }^{1} \mathrm{H} \mathrm{NMR}\left(\mathrm{CDCl}_{3}\right) . \delta 8.44-6.60(\mathrm{~m}, 22 \mathrm{H}$, aromatic), $5.60(1 \mathrm{H}), 4.55(\mathrm{~d}, J 14 \mathrm{~Hz}$, $1 \mathrm{H}), 2.67(\mathrm{~d}, J 14 \mathrm{~Hz}, 1 \mathrm{H}) ;{ }^{13} \mathrm{C} \mathrm{NMR}\left(\mathrm{CDCl}_{3}\right): \delta 213.0,204.5,197.4,142.1,141.8,134.0,138.3$, 137.9 , 136.1, 134.4, 133.0, 131.6, 131.4, 130.7, 130.2, 130.0, 129.500, 128.2, 127.7, 127.7, 
127.3, 127.2, 127.2, 126.7, 126.1, 124.8, 124.5, 122.8, 120.6, 84.7, 71.9, 67.4, 59.7, 47.3; MS: m/z $570\left(\mathrm{M}^{+}\right)$; Anal. Calcd for $\mathrm{C}_{40} \mathrm{H}_{26} \mathrm{O}_{4}$ : C: 84.19, H: 4.59; Found: C: 84.01, H: 4.34 \%; X-Ray data: Unit Cell Parameters: a 9.7277(9) b 10.6312(9) c 15.0319(15); P-1; CCDC 1020924.

2' -(4-Methylbenzoyl)-4'-hydroxy-4' -(4-methylphenyl)-2H,2' H-dispiro[acenaphthylene-1,1'cyclopentane-3',1" -acenaphthylene]-2,2" -dione (5b). Yield 0.7 g (5\%); IR (KBr): 3439 (OH), $1738(\mathrm{C}=\mathrm{O}) \mathrm{cm}^{-1} ;{ }^{1} \mathrm{H}$ NMR $\left(\mathrm{CDCl}_{3}\right): \delta 8.43-6.67$ (m, 20H, aromatic), $4.53(\mathrm{~d}, 1 \mathrm{H}, J 12 \mathrm{~Hz})$, $2.67(\mathrm{~d}, 1 \mathrm{H}, J 14 \mathrm{~Hz}), 2.85\left(\mathrm{~s}, 3 \mathrm{H}, \mathrm{CH}_{3}\right), 2.04\left(\mathrm{~s}, 3 \mathrm{H}, \mathrm{CH}_{3}\right)$.

2' -(4-Chlorobenzoyl)-4' -hydroxy-4' -(4-chlorophenyl)-2H,2' H-dispiro[acenaphthylene-1, 1'cyclopentane-3',1"-acenaphthylene]-2,2"-dione (5c). Yield $1.6 \mathrm{~g}(10 \%) ; \mathrm{mp}>250{ }^{\circ} \mathrm{C}$; IR (KBr): $3348(\mathrm{OH}), 1727(\mathrm{C}=\mathrm{O}) \mathrm{cm}^{-1} ;{ }^{1} \mathrm{H} \mathrm{NMR}\left(\mathrm{CDCl}_{3}\right): \delta 8.40-6.59(\mathrm{~m}, 20 \mathrm{H}$, aromatic), 4.49 (d, $1 \mathrm{H}, J 12 \mathrm{~Hz}), 2.65(\mathrm{~d}, 1 \mathrm{H}, J 16 \mathrm{~Hz})$; MS: $m / z 638\left(\mathrm{M}^{+}\right)$; Anal. Calcd for $\mathrm{C}_{40} \mathrm{H}_{24} \mathrm{Cl}_{2} \mathrm{O}_{4}: \mathrm{C}: 75.12$, H: 3.78; Found: C: 75.01, H: $3.52 \%$.

8-(7,8-Dibenzoyl-7H-cyclopenta[a]acenaphthylen-9-yl)-1-naphthoic acid (6a). Yield $0.45 \mathrm{~g}$ (3\%); $\mathrm{mp}>250{ }^{\circ} \mathrm{C}$; IR (KBr): $3356(\mathrm{OH}), 1686(\mathrm{C}=\mathrm{O}) \mathrm{cm}^{-1} ;{ }^{1} \mathrm{H} \mathrm{NMR}\left(\mathrm{CDCl}_{3}\right): \delta$ 8.06-6.77 (m, 22H, aromatic), 4.79 (s, $1 \mathrm{H})$; MS:- $m / z 568\left(\mathrm{M}^{+}\right)$; Anal. Calcd for $\mathrm{C}_{40} \mathrm{H}_{24} \mathrm{O}_{4}$ : C: 84.49, H: 4.25; Found: C: $84.27, \mathrm{H}: 4.15 \%$.

8-[7,8-Bis(4-methylbenzoyl)-7H-cyclopenta[a]acenaphthylen-9-yl]-1-naphthoic acid (6b). Yield $0.38 \mathrm{~g}(2 \%) ; \mathrm{mp}>250{ }^{\circ} \mathrm{C}$; IR $(\mathrm{KBr}): 3403(\mathrm{OH}), 1712(\mathrm{C}=\mathrm{O}) \mathrm{cm}^{-1} ;{ }^{1} \mathrm{H} \mathrm{NMR}\left(\mathrm{CDCl}_{3}\right): \delta$ 8.87-7.09 (m, 20H, aromatic), 2.43 (s, 3H, $\mathrm{CH}_{3}$ ), 1.96 (s, 3H, $\mathrm{CH}_{3}$ ); MS:- m/z $596\left(M^{+}\right)$; Anal. Calcd for $\mathrm{C}_{42} \mathrm{H}_{28} \mathrm{O}_{4}$ : C: $84.54, \mathrm{H}: 4.73$; Found: $\mathrm{C}: 84.30, \mathrm{H}: 4.63 \%$.

8-[7,8-Bis(4-chlorobenzoyl)-7H-cyclopenta[a]acenaphthylen-9-yl]-1-naphthoic acid (6c). Yield $0.8 \mathrm{~g}(5 \%) ; \mathrm{mp}>250{ }^{\circ} \mathrm{C}$; IR $(\mathrm{KBr}): 3370(\mathrm{OH}), 1732(\mathrm{C}=\mathrm{O}) \mathrm{cm}^{-1} ;{ }^{1} \mathrm{H}$ NMR $\left(\mathrm{CDCl}_{3}\right): \delta$ 8.00-5.30 (m, 20H, aromatic); ${ }^{13} \mathrm{C}$ NMR $\left(\mathrm{CDCl}_{3}\right): \delta 207.6,190.8,179.4,138.7,135.6,134.2$, $134.2,133.8,132.6,131.9,131.7,131.3,130.4,130.3,129.9,129.6,129.2,128.9,128.9,128.4$, 128.1, 127.7, 127.7, 127.2, 126.5, 125.8, 125.6, 124.9, 124.4, 119.8, 103.4, 71.0; MS:- m/z 636 $\left(M^{+}\right)$; Anal. Calcd for $\mathrm{C}_{40} \mathrm{H}_{22} \mathrm{Cl}_{2} \mathrm{O}_{4}$ : C: 75.36, H: 3.48; Found: C: 75.26, H: $3.30 \%$; X-Ray data: Unit Cell Parameters: a 9.1617(6) b 12.5518(8) c 13.9305(8); P-1; CCDC 1024474.

(4-Chlorophenyl)[2-(10-hydroxyphenanthren-9-yl)phenanthro[9,10- $b]$ furan-3-

yl]methanone (21). Yield $0.65 \mathrm{~g}(5 \%) ; \mathrm{mp} 186{ }^{\circ} \mathrm{C}$; IR $(\mathrm{KBr}): 3374(\mathrm{OH}), 1591(\mathrm{C}=\mathrm{O}) \mathrm{cm}^{-1} ;{ }^{1} \mathrm{H}$ NMR $\left(\mathrm{CDCl}_{3}\right): \delta$ 8.79-7.26 (m, 20H), $8.69(\mathrm{~s}, 1 \mathrm{H})$; MS:- $m / z 548\left(\mathrm{M}^{+}\right)$; Anal. Calcd for $\mathrm{C}_{37} \mathrm{H}_{21} \mathrm{ClO}_{3}$ : C: 80.94, H: 3.86; Found: C: 80.82, H: $3.66 \%$; X-Ray data: Unit Cell Parameters: a 9.1617(6) b 12.5518(8) c 13.9305(8); P-1; CCDC 1024475.

\section{Acknowledgements}

We thank STIC, Kochi for NMR, SCXRD and elemental analyses and Kerala Government for financial assistance. RKT gratefully acknowledges CSIR for the award of a senior research fellowship. 


\section{References}

1. Bonne, D.; Coquerel, Y.; Constantieux, T.; Rodriguez, J. Tetrahedron: Asymmetry 2010, 21, 1085. http://dx.doi.org/10.1016/j.tetasy.2010.04.045

2. Xie, Y.-J.; Sun, J.; Yan, C.-G. Comb. Sci. 2014, 16, 271. http://dx.doi.org/10.1021/co500006c

3. Jiang, B.; Fan, W.; Sun, M.-Y.; Ye, Q.; Wang, S.-L.; Tu, S.-J.; Li, G. J. Org. Chem. 2014, 79, 5258.

http://dx.doi.org/10.1021/jo500823z

4. Kumar, S. V.; Perumal, S. Tetrahedron Lett. 2014, 55, 3761. http://dx.doi.org/10.1016/j.tetlet.2014.05.062

5. Arigela, R. K.; Samala, S.; Mahar, R.; Shukla, S. K.; Kundu, B. J. Org. Chem. 2013, 78, 10476. http://dx.doi.org/10.1021/jo401929q

6. Zhao, P.; Yan, X.; Yin, H.; Xi, C. Org. Lett. 2014, 16, 1120. http://dx.doi.org/10.1021/o1500221u

7. Chen, H.; Xie, F.; Gong, J.; Hu, Y. J. Org. Chem. 2011, 76, 8495. http://dx.doi.org/10.1021/jo201384f

8. Kadzimirsz, D.; Kramer, D.; Sripanom, L.; Oppel, I. M.; Rodziewicz, P.; Doltsinis, N. L.; Dyker, G. J. Org. Chem. 2008, 73, 4644. http://dx.doi.org/10.1021/jo8005705

9. Giomi, D.; Cecchi, M. J. Org. Chem. 2003, 68, 3340. http://dx.doi.org/10.1021/jo026761x

10. Volla, M. R. C.; Atodiresei, I.; Rueping, M. Chem. Rev. 2014, 114, 2390. http://dx.doi.org/10.1021/cr400215u

11. Tietze, L. F. Chem. Rev. 1996, 96, 115. http://dx.doi.org/10.1021/cr950027e

12. Poulin, J.; Grisé-Bard, C. M.; Barriault, L. Chem. Soc. Rev. 2009, 38, 3092. http://dx.doi.org/10.1039/b819798a

13. Tietze, L. F.; Brasche. G.; Gericke, K. M. Domino Reactions in Organic Synthesis, WileyVch Verlag GmbH \& Co. KGaA, Weinheim 2006, Chapters 1, 2.

14. Filippini, M. H.; Faure, R.; Rodriguez, J. J. Org. Chem. 1995, 60, 6872. http://dx.doi.org/10.1021/jo00126a044

15. List, B.; Lerner, R. A.; Barbas III, C. F. J. Am. Chem. Soc. 2000, 122, 2395. http://dx.doi.org/10.1021/ja994280y

16. Wang, J.; Li, H.; Xie, H.; Zu, L.; Shen, X.; Wang, W. Angew. Chem. Int. Ed. 2007, 46, 9050.

17. Kozikowski, P. A.; Tückmantel, W. Acc. Chem. Res. 1999, 32, 641. http://dx.doi.org/10.1021/ar9800892 
18. Vadakkan, J. J.; Raman, V.; Fernandez, N. B.; Prathapan, S.; Jose, B. New J. Chem. 2003, $27,239$.

http://dx.doi.org/10.1039/b202454c

19. Sowinski, A. F.; Whitesides, G. M. J. Org. Chem. 1979, 44, 2369.

http://dx.doi.org/10.1021/jo01328a008

20. Lahiri, S.; Dabral, V.; George, M. V. Tetrahedron Lett. 1976, 17, 2259.

http://dx.doi.org/10.1016/0040-4039(76)80044-5

21. Ashby, E. C. Acc. Chem. Res. 1988, 21, 414.

http://dx.doi.org/10.1021/ar00155a005

22. Walling, C. J. Am. Chem. Soc. 1988, 110, 6846.

http://dx.doi.org/10.1021/ja00228a038

23. Ashby, E. C.; Goel, A. B. J. Am. Chem. Soc. 1981, 103, 4983.

http://dx.doi.org/10.1021/ja00406a070

24. Graebe C.; Gfeller, E. Annalen 1893, 1, 276.

25. Jacob, A. M.; Thumpakkara, R. K.; Prathapan, S.; Jose, B. Tetrahedron 2005, 61, 4601. http://dx.doi.org/10.1016/j.tet.2005.03.011

26. Thumpakara, R. K. Ph. D Thesis, CUSAT 2007, 161.

27. Ramirez, F.; Dershowitz, S. J. Org. Chem. 1957, 22, 41. http://dx.doi.org/10.1021/jo01352a010 